\title{
The adaptation in muscle oxidation of leucine to dietary protein and energy intake
}

\author{
By R. D. SKETCHER, E. B. FERN, AND W. P. T. JAMES \\ Clinical Nutrition and Metabolism Unit, Department of Human Nutrition, \\ London School of Hygiene and Tropical Medicine, Keppel Street, \\ London WCI ${ }_{7} H T$
}

(Received 6 June 1973 - Accepted 23 October 1973)

\begin{abstract}
I. Female hooded rats $\left(6_{5} \mathrm{~g}\right)$ were maintained on a high-protein (HP) or low-protein (LP) diet for 2 weeks (ratio, energy supplied by utilizable protein:total metabolizable energy ro and 3.5 respectively) and the oxidation of both $L-$ and $D L-\left[I-{ }^{14} \mathrm{C}\right]$ leucine in vivo was measured in the fed and fasted animal.

2. Oxidation of leucine in vivo was reduced in the animals given the LP diet. Fasting caused an increase in the oxidation of the branched-chain amino acids.

3. Leucine- $\alpha$-oxoglutarate transaminase $(E C 2,6,1.6)$ and $\alpha$-ketoisocaproic acid dehydrogenase were measured in both liver and gastrocnemius muscle from rats fed on the HP or LP diet. Enzymes were also assayed after a $48 \mathrm{~h}$ fast in a group of animals previously maintained on the HP diet.

4. The LP diet led to a fall in muscle dehydrogenase activity without any alterations in liver enzyme activity. Fasting also reduced muscle dehydrogenase activity but increased liver dehydrogenase activity.

5. The presence of a dehydrogenase in muscle and its ability to adapt to dietary stress at a time when the liver enzyme is unaffected suggests that muscle is the most important site for control of leucine oxidation.

6. Transaminase activity in muscle rose in the LP and fasted animals but the activity in liver was unchanged.

7. Oxidation, incorporation into protein of $\left[\mathrm{U}_{-14} \mathrm{C}\right]$ leucine and the pool sizes of free leucine in plasma and in the extensor digitorum longus muscles were measured. The rats were maintained under the feeding conditions described above. The ability of incubated muscles to incorporate $\left[{ }^{14} \mathrm{C}\right]$ leucine into protein in both the fasted animals and those fed on the LP diet was reduced. Oxidation of leucine in muscle was reduced in protein deficiency but there was little change in the evolution of ${ }^{14} \mathrm{CO}_{2}$ from $\left[\mathrm{U}-{ }^{14} \mathrm{C}\right] l$ leucine on fasting.

8. The increase in pool size of free leucine in fasted animals is probably important in determining its rate of oxidation in muscle, as ${ }^{14} \mathrm{CO}_{2}$ production was maintained despite falling activities of the dehydrogenase enzyme activity. The muscle enzyme accounted for $90 \%$ of the calculated body capacity for oxidation; activity in liver is insufficient to deal with normal rates of oxidation. Muscle enzyme is normally in excess of that required for the oxidation of branched-chain amino acids.
\end{abstract}

Leucine oxidation, measured in vivo with $\mathrm{DL}-\left[2{ }^{14} \mathrm{C}\right]$ leucine, has been shown to decrease when an adult rat is given a low-protein diet (McFarlane \& Von Holt, I969a). It has been suggested that this results from a block in the decarboxylation of $\alpha$-ketoisocaproic acid as a result of reduced dehydrogenase activity, as shown in liver mitochondrial preparations (McFarlane \& Von Holt, $1969 b$ ). A similar fall in the dehydrogenase activities for all three branched-chain keto acids has been demonstrated in liver homogenates from animals given a diet containing $90 \mathrm{~g}$ rather than $800 \mathrm{~g}$ casein per kg (Wolhueter \& Harper, 1970). However, Neale (I97r), using uniformly labelled L-amino acids, failed to demonstrate any conservation of either leucine or valine in weanling rats given a diet containing ro $\mathrm{g}$ protein per $\mathrm{kg}$ for 2 weeks. There is also 
evidence that the oxidation of branched-chain amino acids occurs predominantly in extrahepatic tissues, so that the relevance of enzyme changes in the liver to any possible adaptation in leucine oxidation is unclear (Miller, I962). Muscle has been suggested as a major site for the oxidation of the branched-chain amino acids (Young, 1970) because of the high transaminase activity of muscle tissue, although Wolhueter \& Harper (1970) were unable to demonstrate any dehydrogenase activity in muscle preparations.

In view of these discrepancies, we have studied the oxidation of leucine in three ways. First, we have assessed the in vivo oxidation of both the DL- and L-isomers of $\left[{ }^{1-}{ }^{14} \mathrm{C}\right]$ leucine in young rats which were given a high- or low-protein diet with or without fasting. Secondly, we have measured the transaminase and keto-acid dehydrogenase activity in cell-free muscle and liver extracts from these animals. Finally, we used in vitro preparations of intact muscles to assess the effect of diet on leucine decarboxylation and incorporation in muscle.

\section{METHODS}

\section{Animals and diets}

Female hooded rats (Animal Suppliers (London) Ltd, London Ni2) weighing 35-40 $\mathrm{g}$ were housed three to a cage and allowed free access to a powdered diet which contained (g/kg): casein (Casumen: Prideaux Milk Foods, Evercreech, Somerset) rog; maize starch (Corn Products Ltd, Manchester) 426, dextrinized starch (Corn Products Ltd, Manchester) 272, solka floc (cellulose) (Johnson, Jorgensen and Wettre Ltd, London) $9 \mathrm{I}$, arachis oil 45 , mineral salt 45 , B-vitamin mixture ro, fat-soluble vitamin supplement 0.9 and L-methionine (Sigma Chemicals Ltd, London) 0.9 .

Details of the mineral salt mixture, the B-vitamin mixture and the fat-soluble vitamin supplement are given by Payne \& Stewart (1972). The ratio, energy supplied by utilizable protein: total metabolizable energy (NDP:E ratio) was io and it maintained growth at $3 \circ \mathrm{g} / \mathrm{d}$. A low-protein (LP) diet was designed to maintain the animals at a constant weight over a 2-week feeding period and its NDP:E ratio was 3.5 . This diet was the same as the high-protein (HP) diet except that it contained $32.9 \mathrm{~g}$ casein $/ \mathrm{kg}$, the difference being replaced by an equivalent weight of maize starch.

\section{Materials}

All radioactive materials were obtained from the Radiochemical Centre, Amersham, Bucks. Specific activities of amino acids were: $\mathrm{L}-\left[\mathrm{I}-{ }^{14} \mathrm{C}\right] \mathrm{leucine}(60 \mathrm{mCi} / \mathrm{mmol})$, L- $\left[\mathrm{U}-{ }^{14} \mathrm{C}\right]$ leucine ( $10 \mathrm{mCi} / \mathrm{mmol}$ ). 2,5-Diphenyloxazole was obtained from KochLight Laboratories Ltd, Colnbrook, Bucks. Amino acids were from Sigma Chemicals, London, England. All other reagents were from British Drug Houses, Poole, Dorset.

\section{In vivo oxidation}

All rats were maintained on the HP diet until they weighed approximately $65 \mathrm{~g}$. Two groups of animals were given the HP diet and two groups the LP diet for 2 weeks. One of the groups on each dietary regimen was fasted for $48 \mathrm{~h}$; the remaining groups 
were allowed free access to food until $5 \mathrm{~h}$ before testing. The oxidation rate of leucine was assessed by the intragastric injection of $\left[\mathrm{I}^{14} \mathrm{C}\right]$ leucine in a solution of $9 \mathrm{~g} \mathrm{NaCl} / \mathrm{l}$, $\mathrm{pH} 7^{\circ} \circ\left(5^{\circ} \circ \mu \mathrm{Ci} / \mathrm{I} \circ \mathrm{O} \mathrm{g}\right.$ body-weight $)$ as either the $\mathrm{L}$ - or DL-isomer with $\mathrm{I} \mu \mathrm{mol} \mathrm{L}$ leucine/Ioo $\mathrm{g}$ body-weight as a carrier.

Rats were placed in sealed glass containers and expired ${ }^{14} \mathrm{CO}_{2}$ was trapped by drawing the expired air through three sequential tubes, each containing $40 \mathrm{ml}$ of $4 \mathrm{M}-\mathrm{NaOH}$. Trapping was considered to be complete, because the third tube contained less than $\mathrm{I} \%$ of the trapped label. Collections were made for $3 \mathrm{~h}$; the $\mathrm{NaOH}$ was pooled and a $\mathrm{Iml}$ sample was acidified with $2 \mathrm{ml} 2 \mathrm{M}-\mathrm{H}_{2} \mathrm{SO}_{4}$ in a Marie flask. Evolved ${ }^{14} \mathrm{CO}_{2}$ was trapped on filter paper soaked with $0.25 \mathrm{ml}$ phenylethylamine in a centre well. The filter paper was then counted with $\mathrm{I}_{3} \mathrm{ml}$ of a $3: 10(\mathrm{v} / \mathrm{v})$ methanol-toluene mixture, containing $0.4 \% \mathrm{PPO}(2,5$-diphenyloxazole $)$, in a Packard 2420 liquid scintillation counter.

\section{In vitro oxidation in cell-free extracts}

Measurements were made with $\mathrm{L}-\left[\mathrm{I}-{ }^{14} \mathrm{C}\right]$ leucine in tracer doses on tissues from rats maintained on the same dietary regimen as described above, but only animals previously given the diet with an NDP: $\mathrm{E}$ ratio of Io were fasted. Liver and gastrocnemius muscles were removed, frozen with solid $\mathrm{CO}_{2}$ and stored at $-18^{\circ}$ for subsequent assay. Preliminary experiments revealed no deterioration in enzyme activities during the storage period. Leucine $\alpha$-oxoglutarate transaminase (EC 2.6. I .6) and $\alpha$-ketoisocaproic acid dehydrogenase activities were measured in both liver and muscle by a modification of the assay system described by McFarlane \& Von Holt (r969b). Both liver and muscle were homogenized by hand in a Dual glass homogenizer. Hand homogenization was necessary, because preliminary work demonstrated a destruction of dehydrogenase activity if more vigorous techniques, e.g. Polytron homogenization, were used.

Optimum assay conditions were assessed for both transaminase and dehydrogenase activity in liver and muscle, with respect to their $\mathrm{pH}$ maxima, substrate concentration of leucine and $\alpha$-oxoglutarate and cofactor requirements. For muscle, final concentrations of ro mmol leucine $/ 1$ and I $5 \mathrm{mmol} \alpha$-oxoglutarate $/ 1$ were used, at $\mathrm{pH} 7 \cdot 0$ in 25 mm-Sorensen's phosphate buffer (disodium hydrogen phosphate, $25 \mathrm{mmol} / \mathrm{l}$ and potassium dihydrogen phosphate, $25 \mathrm{mmol} / \mathrm{l}$, adjusted to $\mathrm{pH} 7 \cdot 0$ ); for liver the same system was used, except that the final concentration of $\alpha$-oxoglutarate was ro $\mathrm{mmol} / \mathrm{l}$. Counts were proportional to homogenate concentrations, and linear for the $60 \mathrm{~min}$ period of assay at $37^{\circ}$.

In the first stage of the assay the ${ }^{14} \mathrm{CO}_{2}$ evolved was taken as a measure of the dehydrogenase activity of the crude homogenate sample. Allowance had been made for the non-specific evolution of ${ }^{14} \mathrm{CO}_{2}$ from $\mathrm{L}-\left[\mathrm{I}^{14} \mathrm{C}\right]$ leucine on the addition of $2 \mathrm{M}$ $\mathrm{H}_{2} \mathrm{SO}_{4}$ at the end of the incubation. After centrifugation of the incubation mixture at $3000 \mathrm{~g}$ for $\mathrm{Io} \mathrm{min}, \mathrm{I} \mathrm{ml}$ of the supernatant fraction was assayed for residual $\left[{ }^{14} \mathrm{C}\right] \mathrm{keto}$ acid by chemical decarboxylation with saturated ceric sulphate in $2 \mathrm{M}^{-} \mathrm{H}_{2} \mathrm{SO}_{4}$. Nonspecific evolution of ${ }^{14} \mathrm{CO}_{2}$ from $\left[\mathrm{I}^{14} \mathrm{C}\right]$ leucine was also measured at this step. The label released by ceric sulphate in addition to that from the initial decarboxylation of leucine represented total transaminated label and was used to calculate the total 
transaminase activity. The protein content of the homogenate used for enzyme assay was measured by autoanalysis by the technique of Lowry, Rosebrough, Farr \& Randall (195I).

\section{Oxidation, incorporation into protein and pool sizes in intact muscle}

Incubation experiments with extensor digitorum longus (EDL) muscle using $\mathrm{L}-\left[\mathrm{U}-{ }^{14} \mathrm{C}\right] \mathrm{leucine}$ were performed as described by Pain \& Manchester (1970). The medium contained Krebs-Ringer bicarbonate buffer (Umbreit, Burris \& Stauffer, 1959) gassed with a mixture of $\mathrm{O}_{2}$ and $\mathrm{CO}_{2}(95: 5)$.

The pool sizes of amino acids in the EDL muscle and plasma were measured in the different dietary groups on a Locarte amino acid analyser (Floor Model; Locarte, 24 Emperors Gate, London) using lithium citrate buffers as described by Kedenburg (197I). Sulphosalicylic acid solution ( $5 \circ \mathrm{g} / \mathrm{l})$ was used as a protein precipitant with roo mmol norleucine $/ \mathrm{l}$ as a quantitative internal standard.

\section{Statistical treatment of results}

Students' $t$ test was used to estimate the significance of results.

\section{RESULTS}

\section{In vivo oxidation}

In vivo oxidation of $\mathrm{DL}-\left[\mathrm{I}-{ }^{14} \mathrm{C}\right]$ leucine was greater than of $\mathrm{L}-\left[\mathrm{I}^{14} \mathrm{C}\right]$ leucine in animals given a control HP diet (Table I). Except for DL- $\left[\mathrm{I}-{ }^{14} \mathrm{C}\right]$ leucine oxidation in fasted control animals, fasting produced a marked increase in the evolution of ${ }^{14} \mathrm{CO}_{2}$, and fasting of the protein-depleted animals restored the output to near normal levels (Table r). Assay of the activity of the first two enzymes in the oxidative pathway of leucine (Table 2) showed them to be present not only in liver but also in gastrocnemius muscle. Dehydrogenase activity was clearly demonstrated in the gastrocnemius muscle of animals on all three dietary regimens, and was present in greater activity/mg protein than that found in liver.

Muscle transaminase activity was even higher, and was approximately ten times as great per mg protein as that in liver. Thus the ratio, transaminase activity: ketoacid dehydrogenase activity was much higher in muscle.

The enzymes in liver and muscle differed not only in their levels of activity but also in their response to dietary stress. Low-protein feeding produced a rise in muscle transaminase activity but a fall in dehydrogenase activity to less than half the control value. In contrast, liver transaminase and dehydrogenase activities were not changed appreciably. Thus in vivo conservation of injected $\left[\mathrm{I}-{ }^{14} \mathrm{C}\right]$ leucine (Table $\mathrm{I}$ ) was occurring without any change in liver dehydrogenase activity, which hitherto has been held responsible for the reduced oxidation of $\alpha$-ketoisocaproic acid in proteindepleted animals (McFarlane \& Von Holt, I $969 a, b$ ). The experiments with fasted rats indicated that changes in enzyme activity (Table 2) could occur rapidly, for within $48 \mathrm{~h}$, muscle dehydrogenase activity had fallen markedly. In contrast, liver dehydrogenase activity rose. 
Table I. In vivo oxidation of $\left[\mathrm{I}^{14} \mathrm{C}\right]$ leucine using either the $\mathrm{DL}$ - or $\mathrm{L}$-isomer in rats given a high-or a low-protein diet or fasted

(Mean values with their standard errors where given)

\begin{tabular}{|c|c|c|c|c|}
\hline Isomer & $\begin{array}{l}\text { No. of rats } \\
\text { in group }\end{array}$ & $\begin{array}{l}\text { NDp: } \mathrm{E} \text { ratio } \\
\text { of diet* }\end{array}$ & $\begin{array}{l}\text { Whether fasted } \\
\text { for } 48 \mathrm{~h}\end{array}$ & $\begin{array}{l}\text { Evolved }{ }^{14} \mathrm{CO}_{2} \\
\text { (\% of dose given) }\end{array}$ \\
\hline \multirow[t]{4}{*}{$\mathrm{DL}$} & 2 & 10 & - & $31 \cdot 3$ \\
\hline & 2 & 10 & + & 27.0 \\
\hline & 3 & $3 \cdot 5$ & - & II.I $\pm 0.8 a$ \\
\hline & 3 & $3 \cdot 5$ & + & $22 \cdot 0 \pm 3 \cdot 2 a$ \\
\hline \multirow[t]{4}{*}{$\mathbf{L}$} & 3 & 10 & - & $15.9 \pm 0.3 b c$ \\
\hline & 3 & 10 & + & $29 \cdot 0 \pm 3.2 c$ \\
\hline & 3 & $3 \cdot 5$ & - & $4 \cdot a \pm 1 \cdot 0 b$ \\
\hline & 2 & $3 \cdot 5$ & + & I 0.9 \\
\hline
\end{tabular}

Statistical comparison of groups : values marked with the same letter differ significantly at the following levels: $a, P<0.01 ; b, P<0.001 ; c, P<0.02$.

* Ratio, energy supplied by utilizable protein: total metabolizable energy.

Table 2. Leucine $\alpha$-oxoglutarate transaminase and $\alpha$-ketoisocaproic acid dehydrogenase activities of liver and muscle homogenates in rats either given a high- or a lowprotein diet or fasted for $48 \mathrm{~h}$

(Mean values with their standard errors for six rats per group)

\begin{tabular}{|c|c|c|c|c|}
\hline \multirow[b]{2}{*}{ Tiss ue } & \multirow[b]{2}{*}{$\begin{array}{l}\text { NDp:E ratio } \\
\text { of diet* }\end{array}$} & \multirow[b]{2}{*}{$\begin{array}{c}\text { Whether fasted } \\
\text { for } 48 \mathrm{~h}\end{array}$} & \multicolumn{2}{|c|}{$\begin{array}{l}\text { Activity of enzymes (nmol leucine or } \\
\text { keto acid oxidized/mg protein per } \mathrm{h} \text { ) }\end{array}$} \\
\hline & & & $\begin{array}{c}\text { Leucine } \\
\alpha \text { moxoglutarate } \\
\text { transaminase }\end{array}$ & $\begin{array}{c}\alpha \text {-Ketoisocaproic } \\
\text { acid } \\
\text { dehydrogenase }\end{array}$ \\
\hline Muscle & I0 & - & $69 \cdot 6 \pm 3 \cdot 33 c$ & $2.15 \pm 0.20 a b$ \\
\hline Muscle & 10 & + & $72 \cdot 3 \pm 2 \cdot 31 d$ & $\mathrm{x} \cdot 28 \pm 0.17 b$ \\
\hline Muscle & 3.5 & - & $86.8 \pm 2.84 c d$ & $0.91 \pm 0.07 a$ \\
\hline Liver & IO & - & $6.5 \pm 0.60$ & $0.68 \pm 0.07 e$ \\
\hline Liver & Io & + & $7.8 \pm 0.44$ & $0.99 \pm 0.07 \mathrm{ef}$ \\
\hline Liver & $3 \cdot 5$ & - & $6.6 \pm 0.44$ & $0.65 \pm 0.04 f$ \\
\hline
\end{tabular}

Statistical comparison of groups: values marked with the same letter differ significantly at the following levels: $a, P<0.00 \mathrm{I} ; b, c, d, e$ and $f, P<0.0 \mathrm{I}$.

* Ratio, energy supplied by utilizable protein : total metabolizable energy.

\section{In vitro incubation studies}

Table 3 shows that, when the same medium concentration of labelled leucine was used for incubating EDL muscle from fasted, fed and protein-depleted animals, there were marked differences in the incorporation of label into protein and in the evolution of ${ }^{14} \mathrm{CO}_{2}$. The protein concentration of the muscles was similar in all three groups, so that the results imply equivalent changes per $\mathrm{g}$ tissue. Low-protein feeding reduced the incorporation of label into protein to half the normal level, with an equivalent fall in the amount evolved as ${ }^{14} \mathrm{CO}_{2}$. In fasted rats there was a greater fall in incorporation into protein but no significant change in ${ }^{14} \mathrm{CO}_{2}$ output. Thus, if precursor leucine concentration levels within muscle were equal in all three groups, low-protein feeding 
with glycine, lysine and tyrosine that only $30 \%$ of amino acids liberated by muscle protein breakdown are recycled for protein synthesis within muscle, compared with a reutilization rate of $50 \%$ for amino acids from liver protein (Watcrlow \& Stephen, 1968; Garlick, 1969; P. J. Garlick, D. J. Millward \& W. P. T. James, unpublished observations). On this basis, the turnover of muscle protein is more likely to make amino acids available for catabolism than is the turnover of liver protein.

A low-protein diet, sufficient only to maintain the weight of the rats, led to a change in muscle $\alpha$-ketoisocaproic acid dehydrogenase activity before any alterations in liver enzyme activities were discernable. McFarlane \& Von Holt's (1969 $a, b)$ work demonstrates that either more severe or more prolonged depletion can lead to adaptation in the liver enzyme activity, but the changes observed in the present experiments with only moderately low protein intakes suggest that muscle is an important organ in limiting the oxidation of leucine; muscle enzyme changes occur in association with in vivo alterations in leucine catabolism at a time when no change in liver enzyme activity has occurred. The incubation studies with intact muscles confirm that leucine oxidation occurs within muscle, and teinforce our demonstration of decarboxylation activity within this tissue. Odessey \& Goldberg (1972) have also recently shown that evolution of ${ }^{14} \mathrm{CO}_{2}$ from $\left[\mathrm{I}-{ }^{14} \mathrm{C}\right]$ leucine occurs from incubated skeletal muscle.

\section{The significance of dehydrogenase activity}

The maximum capacity of the dehydrogenase enzymes in muscle can be calculated from Table 2 if muscle protein is assumed to be $50 \%$ of total body protein. Thus the maximum capacity for muscle to oxidize leucine is $0.52 \mathrm{mmol} / \mathrm{d}$. This compares with a flux rate of leucine through the plasma which can be calculated from the results of Loftfield \& Harris (1956) to be approximately $3^{\circ} \circ \mathrm{mmol} / \mathrm{d}$. The total body content of leucine may be taken as $\mathrm{r} 6.5 \mathrm{mmol}$ (Munro \& Fleck, 1969 ), with a daily intake of 0.8 $\mathrm{mmol}$, for a $100 \mathrm{~g}$ rat. At the growth rates of animals in the present experiment, 0.5 mmol leucine would be deposited as new tissue daily, so that the input of leucine for catabolism, i.e. $0.3 \mathrm{mmol}$, is half the known capacity of muscle for oxidizing the leucine. Our results (Table 2) and the tissue distribution of dehydrogenase activity (Wolhueter \& Harper, 1970) show that liver accounts for only $2 \%$ of the body's dehydrogenase activity, with $<0.05 \%$ for brain and $<0.05 \%$ for kidney; the combined activity of these tissues would be insufficient for the required oxidation. Muscle must therefore play an important part in the regulation of branched-chain amino acid oxidation.

\section{Adaptation to dietary content of protein and energy}

The reduction in DL-leucine oxidation with low-protein feeding, seen by McFarlane \& Von Holt (1969a) in adult rats, has been confirmed in our work with young growing animals. The use of the L-isomer of leucine has also shown that the results reflect changes in the normal leucine catabolic pathway and do not reflect alterations in the activity of D-amino acid oxidase $(E C I \cdot 4 \cdot 3 \cdot 3)$.

The results of Neale (I97I), showing a failure of weanling rats to conscrve leucine, indicate that adaptation in branched-chain amino acid catabolism may only develop 
fully after weaning, although our experiments on weanling animals (Sketcher \& James, unpublished observations) do not confirm these findings. Neale (1972) also studied the oxidation in vivo of valine in eviscerated and control adult rats given a protein-free diet and failed to show any adaptation in oxidation by peripheral tissues.

Those experiments were done with [U-14 C]-labelled amino acids. P. J. Reeds (1973, personal communication) has demonstrated that the output of ${ }^{14} \mathrm{CO}_{2}$ from uniformly labelled valine does not follow the same pattern as that from $\left[\mathrm{I}^{11} \mathrm{C}\right]$ valine. It must also be emphazised that the proportion of dose excreted as ${ }^{14} \mathrm{CO}_{2}$ is not an accurate measure of the amount of amino acid oxidized, because the pool size may vary. As shown in Table 4, the pool size of free leucine decreased in LP rats and rose with starvation. The effect of this is that a given output of ${ }^{14} \mathrm{CO}_{2}$ represents a smaller amount of amino acid oxidized in the LP rats and a larger amount in the starved rats. Conclusions based on the proportion of a dose excreted are valid only in terms of the fractional rather than the absolute catabolic rate of the free pool of amino acid.

\section{Interrelationship of liver and muscle in fasting state}

The experiments with fasted animals show that both liver and muscle keto-acid dehydrogenase activities alter significantly within $48 \mathrm{~h}$. Muscle enzyme activity is, however, diminished, whereas liver enzyme activity increases. These changes may be functionally important. Analysis of results for the efflux of amino acids in muscle of man under fasting conditions (Pozefsky, Felig, Jordan, Soeldner \& Cahill, I969) suggests that leucine is released from muscle in far smaller quantities than those to be expected from the known amounts of leucine in muscle protein. Transamination, with the donation of the amino group from leucine to alanine or glutamine (Felig \& Wahren, I97 $\mathrm{x}$, would be facilitated by the high concentrations of transaminase present in muscle (Young, 1970). This transamination seems to occur more readily than is normal, because, despite the net breakdown of muscle protein with the production of more leucine, there is no great accumulation of free leucine within muscle (Table 4 ). If the subsequent step of decarboxylation were not rate-limiting, then an increased provision of substrate would increase keto-acid oxidation despite the lowered dehydrogenase activity. Any limitation in decarboxylation could also allow the excess keto acid to pass from muscle to liver, where the increased dehydrogenase activity would aid its further oxidation. This would certainly be a mechanism whereby liver could derive energy from the carbon skeleton of branched-chain amino acids present in high concentration in muscle protein. The incubation experiments (Table 3) provide a direct demonstration of the oxidation of leucine to carbon dioxide within muscle. Goldberg's (1972) experiments with diaphragm also suggested that the keto acid of leucine is oxidized within muscle, and Ruderman (quoted by Krebs, 1972) has demonstrated in a hind-limb perfusion the release of ketone bodies from muscle during perfusions with lcucine. The incubation experiments (Table 3 ) allow an approximate estimate to be made of the rate of leucine oxidation in the incubated muscles, as the initial higher concentration of leucine within the cell in vivo (Table 4) will fall when the muscle is incubated as the exchange of leucine occurs rapidly with the large pool of leucine of constant specific activity (Hider, Fern \& London, 1971). Thus, the 
intracellular specific activities were probably similar in the different groups of muscles, and the output of ${ }^{14} \mathrm{CO}_{2}$ would be a valid measure of the amount of leucine oxidized. Different rates of catabolism could occur in vivo, however, when the pool size of leucine changes in response to the diet. Goldberg \& Odessey (1972) have recently reported a greater increase on fasting in the ${ }^{14} \mathrm{CO}_{2}$ production from leucine in diaphragm muscle than that seen in the present experiments. In their incubations $\left[{ }^{1}-{ }^{14} \mathrm{C}\right]-$ labelled leucine was used, thus eliminating any problems which might arise from incomplete oxidation of labelled degradative products of $\left[\mathrm{U}^{14} \mathrm{C}\right]$ leucine (Meikle \& Klain, I972; P. J. Reeds, 1973, personal communication). Since fasting does not normally lead to a large increase in the plasma concentration of keto acids (Tanaka, Isselbacher \& Shih, I972) and the capacity of liver for oxidizing keto acid is limited, it is likely that muscle plays an important part in the increased oxidation of leucine during fasting.

\section{Control of leucine catabolism in muscle}

The similar fall in keto-acid dehydrogenase activity in muscle of fasted and of protein-depleted animals, together with the very different calculated rates of leucine oxidation in muscle in the same two dietary states, suggests that the enzyme cannot be solely responsible for determining the oxidation rate of leucine. Furthermore, its capacity, as indicated above, is in excess of the actual rates. The $K_{m}$ of the dehydrogenase activity in liver mitochondria has been shown to be $0.2 \mathrm{mmol} / \mathrm{l}$ (Wolhueter \& Harper, $197^{\circ}$ ). If the muscle enzyme has the same $K_{m}$, then the concentrations of leucine within muscle are themselves in the approximate range in which the oxidation rates will be determined by the leucine concentration. It is unlikely that the intracellular pool of amino acid is homogenous so that variations in leucine concentrations greater than those seen for the whole tissue (Table 4) may occur at the precursor site for oxidation. Thus an enhanced absolute rate of oxidation may occur in muscle in starvation despite a fall in the enzyme capacity for oxidation.

Perhaps of more importance than the measured concentration of substrates is the problem of compartmentation. Waterlow \& Stephen ( 1968 ) have shown that muscle protein turnover is more rapid than previously thought, with a $T_{\frac{1}{2}}$ of $7-8 \mathrm{~d}$. This has been confirmed with another technique which measures the synthesis and breakdown components of muscle protein turnover (Millward, 1970). This rapid turnover is accompanied by recycling of amino acids, particularly of the essential amino acids. The small intracellular pool of leucine, therefore, must be turning over extremely rapidly. Penetration of leucine to the intracellular compartment for oxidation may then limit the catabolism of leucine. In anatomical terms the mitochondria with their keto-acid dehydrogenases are placed around the muscle myofibrils (Ham, 1957), so that intramitochondrial penetration may be a rate-limiting step. Finally, transamination of leucine with net production of $\alpha$-ketoisocaproic acid depends on the availability and relative concentrations of the other reactants in this reversible process. The changes in the concentration of these reactants in different nutritional states are unknown. Defining the rate-limiting steps in leucine oxidation in muscle, therefore, must await more detailed studies with measurements of leucine turnover and labelled $\alpha$-ketoisocaproate oxidation in a physiological preparation of muscle. The present 
results, however, suggest that muscle plays an important part in determining the rate of leucine oxidation under conditions of nutritional stress.

\section{REFERENCES}

Felig, P. \& Wahren, J. (197 I). F. clin. Invest. 50, 2703.

Garlick, P. J. (r969). Nature, Lond. 223, 6r.

Goldberg, A. L. (1972). In Muscle Biology Vol. I, p. 98 [R. G. Cassens, editor]. New York: M. Dekker Inc.

Goldberg, A. L. \& Odessey, R. (1972). Am. Y. Physiol. 223, 1384.

Ham, A. W. (1957). Histology p. 338. London: Pitman Medical.

Hider, R. C., Fern, E. B. \& London, D. R. (1971). Biochem. F. 121, 817.

Kedenburg, C. P. (r97r). Analyt. Biochem. 40, 35 .

Krebs, H. A. (1972). In Advances in Enzyme Regulation Vol. тo, p. 387 [G. Weber, editor]. New York: M. Dekker Inc.

Lowry, O. H., Rosebrough, N. J., Farr, A. L. \& Randall, R. J. (195 I). F. bial. Chem. 193, 265.

Loftfield, R. B. \& Harris, A. (1956). F. biol. Chem. 2I9, I5

McFarlane, I. G. \& Von Holt, C. (Ig6ga). Biochem. F. III, 557.

McFarlane, I. G. \& Von Holt, C. (19696). Biochem. F. 111, 565.

Meikle, A. W. \& Klain, G. J. (1972). Am. F. Physiol. 222, 1246.

Miller, L. L. (1962). In Amino Acid Pools p. 708 [J. T. Holden, editor]. Amstcrdam: Elsevier.

Millward, D. J. (1970). Clin. Sci.39, 59 r.

Munro, H. N. \& Fleck, A. (1969). In Mammalian Protein Metabolism Vol. 2, p. 424 [H. N. Murro, editor] New York and London: Academic Press.

Neale, R. J. (1971). Nature Nezo Biol. 231, I 17.

Neale, R. J. (1972). Biochim. biophys. Acta 273, 80.

Odessey, R. \& Goldberg, A. L. (1972). Am. F. Physiol. 223, 1376.

Pain, V. M. \& Manchester, K. L. (r970). Biochem. F. I18, 209.

Payne, P. R. \& Stewart, R. J. C. (1972). Lab. Anim. 6, r35.

Pozefsky, T., Felig, P., Jordan, D. T., Soeldner, J. S. \& Cahill, F. G. Jr ( ( 969). J. clin. Invest. 48, 2273.

Tanaka, K., Isselbacher, K. J. \& Shih, V. (1972). Science, N.Y. 175, 69.

Umbreit, W. W. Burris, R. H. \& Stauffer, J. K. (editors) (1959). Manometric Methods p.r49. Minneapolis: Burgess Publishing Company.

Waterlow, J. C. \& Stephen, J. M. L. (1968). Clin. Sci. 35, 287.

Wolhueter, R. M. \& Harper, A. E. (1970). F. biol. Chem. 245, 2391.

Young, V. R. (1970). In Mammalian Protein Metabolism Vol. 4, p. 612 [H. N. Munro, editor]. New York and London: Academic Press. 